\title{
Effect of particle size and oxidant concentration in the yield of humic acids from mineral coal using response surface methodology
}

\author{
Adolfo A. Pájaro-Payares ${ }^{1}$, Eduardo A. Espinosa-Fuentes², Fredy Colpas-Castillo ${ }^{1}$, Johana Rodríguez-Ruiz ${ }^{3}$, \\ Roberto Fernández-Maestre ${ }^{1}$, Edgardo Meza-Fuentes ${ }^{1, *}$ \\ ${ }^{1}$ Universidad de Cartagena, Campus San Pablo, Cartagena, Colombia \\ ${ }^{2}$ Corporación Universidad de la Costa, Barranquilla, Colombia \\ ${ }^{3}$ SENA-Centro para la Industria Petroquímica, Cartagena, Colombia
}

\begin{abstract}
Humic acids are produced by decomposition of organic soil material and from oxidation of mineral coals. In this study, the effect of oxidation and the yield of humic acids extracted from a sample of Colombian mineral coal were studied by response surface methodology (RSM). The variables used were: particle size $(0.063,0.106$ and 0.150 $\mathrm{mm})$, concentration of the oxidizing agent $\left(\mathrm{KMnO}_{4}: 0.010,0.020\right.$ and $\left.0.050 \mathrm{M}\right)$ and oxidation time $(30,60$ and 90 minutes). The degree of oxidation was verified by infrared spectroscopy. Oxidation increased oxygen groups in the carbonaceous matrix, mainly due to oxidation of aliphatic components. Extraction yields above $24 \%$ were obtained with $0.063 \mathrm{~mm}$ particle size and 0.020 $\mathrm{M} \mathrm{KMnO}_{4}$. C 2017. Acad. Colomb. Cienc. Ex. Fis. Nat.
\end{abstract}

Key words: bituminous coal; humic acids; oxidation process; surface response; factorial design.

Efecto del tamaño de partícula y la concentración del oxidante en el rendimiento de ácidos húmicos obtenidos de carbón mineral proveniente de Colombia usando la metodología de superficie de respuesta

Resumen

Los ácidos húmicos se producen por la descomposición de la materia orgánica de los suelos y por la oxidación de carbones minerales. En este estudio se analizó mediante superficies de respuesta el efecto de la oxidación en la extracción de ácidos húmicos de un carbón colombiano. Las variables de oxidación estudiadas fueron las siguientes: tamaño de partícula $(0,063,0,106$ y $0,150 \mathrm{~mm})$, concentración del agente oxidante (permanganato de potasio $\left(\mathrm{KMnO}_{4}\right): 0,010,0,020$ y $\left.0,050 \mathrm{M}\right)$ y tiempo de oxidación (30, 60 and 90 minutos). El grado de oxidación se verificó con espectroscopia infrarroja. La oxidación incrementó los grupos oxigenados en la matriz carbonácea debido, principalmente, a la oxidación de componentes alifáticos. Se obtuvieron porcentajes de extracción superiores a $24 \%$ al usar partículas de 0,063 mm y $\mathrm{KMnO}_{4}$ con 0,020 M. (C) 2017. Acad. Colomb. Cienc. Ex. Fis. Nat.

Palabras clave: carbon bituminoso; ácidos húmicos; oxidación; superficie de respuesta; diseño factorial.

\section{Introduction}

Humic substances are essential components of soil and natural waters produced by chemical and biological decomposition of animal and vegetal materials. These compounds are widely distributed in soils in the form of amorphous and colloidal solids in combination with the rest of the organic matter, and in water sources forming micelles due to their amphiphilic character (Maccarthy, 2001; Gomes, et al., 2016; Zhang, et al., 2017, Klučáková \& Věžníková, 2017).

The main humic substances can be classified as fulvic acids, humic acids and humins. Separation methods of humic compounds depend on their solubility in acid or basic media. Humic acids are insoluble in acids and soluble at neutral and alkaline $\mathrm{pH}$, fulvic acids are soluble at any $\mathrm{pH}$ and in water, and humins are insoluble in any medium. Humic acids are traditionally described as aggregates of macromolecules with high molecular weight (1,500 to 500,000 Da) (Gomes, et al., 2016; Raposo, et al., 2017). They have several oxygenated functionalities as carboxylic, phenolic, enolic, hydroxyl, quinone, sugars and peptide groups (Jones \& Bryan, 1998; Kumada, 1987; Kawasaki, et al., 2008; Yang, et al., 2015), which give them a hydrophilic character, and aliphatic and aromatic groups that confer them hydrophobic characteristics (Gomes, et al., 2016). Recent studies indicate that humic acids are constituted by supramolecular clusters formed by the assembly of bio-molecules through chemical bonds such as hydrogen bonds, and hydrophobic and Van der Waals interactions (Nebbioso \& Piccolo, 2012).

\footnotetext{
*Corresponding autor:

Edgardo Meza-Fuentes, emezaf@unicartagena.edu.co

Received: May 8, 2017

Accepted: August 31, 2017
} 
The amount and type of chemical functionalities of humic substances depend on the genesis conditions: weather, time of formation, the starting material and biological conditions (Stevenson, 1994). The structure of humic acids obtained from coals depends markedly on the geological formation process and the region of the coal reservoir. The chemical properties of humic acids depend mainly on the carboxylic and phenolic groups, which are deprotonated in alkaline medium. This deprotonation generates negative charges that increase the repulsion between charged groups, stretch the molecular aggregates and increase the solubility of the humic acids due to the increase of their polar character, which also improves the exchange capacity of the groups on the surface of the macromolecules with cations of the medium (Gomes, et al., 2016).

Humic acids are important for the nutrition of plants because they contribute to retention of nutrients and water, they are a growth medium of microorganisms, and slowly release the main elements for the nutrition of plants. Among the most outstanding applications of humic acids are fertilization, retention of metals, pollution remediation by removal of toxic substances from aqueous effluents, and applications in the medical, pharmaceutical and cosmetics areas (Simeoni, et al., 2003; Klučáková \& Kalina, 2015; Liang, et al., 2011; Shaker \& Albishri, 2014; Martínez-Fernández, et al., 2014, Tejeda-Agredano, et al., 2104; Tang, et al., 2017; Saldaña ${ }_{2}$ et al., 2017; Rashid, et al., 2017).

A great source of humic compounds are low rank mineral coals (lignites) and oxidized bituminous coals (EspinosaFuentes, et al., 2017). The structure of this type of compounds consists of polycondensed aromatic rings linked through bridges of the alkylene-, ether- or ester-like bonds. These aromatic structures are also linked to carboxylic and phenolic groups and to aliphatic chains (Kurková, et al., 2004). Due to environmental problems of the energy applications of coal it is important to find alternative uses for low-grade coals, such as production of activated carbon, building materials, carbon fibers and humic acids for soil fertilization and remediation (Kwiatkowska, et al., 2008).

When fossil coals are subjected to mild oxidation reactions a partial degradation of the organic matter occurs, leading to an increasing number of functionalities containing oxygen, such as phenolic and carboxylic groups (Van Krevelen, 1993; Taraba, 1990). This increases the yield of humic acids in the coals, also leading to higher extraction yields of these materials (Skybová, et al., 2007; Lobartini, et al., 1992). Coal oxidation processes are usually carried out with air at moderate temperatures or dilute solutions of $\mathrm{H}_{2} \mathrm{O}_{2}, \mathrm{HNO}_{3}$ or $\mathrm{KMnO}_{4}$, in order to maximize the degree of formation of carboxylic and phenolic groups and minimize the decomposition of the organic matter to $\mathrm{CO}_{2}$.

In this work, we used coal from El Cerrejón mine in Colombia. This mine produces about 32 MT of coal annually and generates more than 12,000 jobs, and it is one of the largest and most important companies in the country.
Most of this coal is for energy production, which generates large emissions of polluting gases such as carbon dioxide and sulfur compounds. For this reason, it is important to give this mineral an alternative use as a source of humic acids for the nutrient enrichment of soils and the production of $\mathrm{CO}_{2}$-collecting biomass. To achieve this objective first it was necessary to know the effect of the concentration of $\mathrm{KMnO}_{4}$ and particle size on the oxidation and yield of humic substances. $\mathrm{KMnO}_{4}$ is a low cost and easy to handle oxidant and the particle size can be quickly obtained with easily accessible instruments such as ball or screw mills. The experiments were planned with a type $3^{3-1}$ fractional factorial design and RSM to minimize the number of experiments and the cost of the research (Anillo-Correa, et al., 2013; Calemma, et al., 1994; Barros, et al., 1996; Morgenthaler \& Schumacher, 1999).

\section{Materials and methods}

A sample of coal $(200 \mathrm{~g})$ was demineralized with $0.5 \mathrm{M}$ hydrochloric acid, and then it was washed with deionized water up to a conductivity value of $0.05 \sigma \mathrm{S} / \mathrm{cm}^{-1}$. Samples were stored in portions of $5 \mathrm{~g}$. To increase the humic acids content, the demineralized sample was oxidized with aqueous solutions of $\mathrm{KMnO}_{4}$ at room temperature using $100 \mathrm{~mL}$ of solution for each $5 \mathrm{~g}$ of coal. The coal samples were extracted from El Cerrejón mine, Colombia.

To optimize and minimize the number of experiments, a fractional factorial design $3^{3-1}$ was used (Table 1). The experimental variables and ranges used were particle size (0.063, 0.106 and $0.150 \mathrm{~mm})$, concentration of the oxidizing agent $(0.01,0.02$ and $0.05 \mathrm{M})$ and oxidation time $(30,60$ and 90 minutes).

Humic substances were separated from the reaction mixture using a $0.1 \mathrm{M}$ solution of potassium hydroxide, 160 $\mathrm{mL}$ per each $5 \mathrm{~g}$ of sample; the extractions were performed with portions of $20 \mathrm{~mL}$ of $\mathrm{KOH}$ solution for 30 minutes at 200 $\mathrm{rpm}$ and the resulting solutions were then filtered to remove coal residues. To precipitate humic acids, an excess of $0.2 \mathrm{M}$

Table 1. Fractional factorial design $3^{3-1}$ and values of experimental variables used for the oxidation of coal

\begin{tabular}{ccccccc}
\hline Experiment & \multicolumn{2}{c}{$\begin{array}{c}\text { Particle size } \\
(\mathbf{m m})\end{array}$} & $\begin{array}{c}\text { Concentration } \\
(\mathbf{M})\end{array}$ & Time & $(\mathbf{m i n})$ \\
\hline 1 & -1 & 0.063 & -1 & 0.01 & -1 & 30 \\
\hline 2 & -1 & 0.063 & 0 & 0.02 & 1 & 90 \\
\hline 3 & -1 & 0.063 & 1 & 0.05 & 0 & 60 \\
\hline 4 & 0 & 0.106 & -1 & 0.01 & 1 & 90 \\
\hline 5 & 0 & 0.106 & 0 & 0.02 & 0 & 60 \\
\hline 6 & 0 & 0.106 & 1 & 0.05 & -1 & 30 \\
\hline 7 & 1 & 0.150 & -1 & 0.01 & 0 & 60 \\
\hline 8 & 1 & 0.150 & 0 & 0.02 & -1 & 30 \\
\hline 9 & 1 & 0.150 & 1 & 0.05 & 1 & 90 \\
\hline
\end{tabular}


$\mathrm{HCl}$ solution was added. The product was filtered after 24 hours and washed with distilled water. These products were dried at $40{ }^{\circ} \mathrm{C}$ for 24 hours and then weighed, in order to calculate the extraction yield of humic acids. The process was performed in triplicate.

The Colombian coal sample was characterized by elemental analysis (carbon, nitrogen, hydrogen, sulfur and oxygen), thermogravimetric analysis (TGA), differential scanning calorimetry (DSC) and Fourier transform infrared spectroscopy (FTIR). The humic acid samples were characterized by FTIR to study the effect of the oxidation on the chemical characteristics of coal under different conditions. Elemental analysis was performed on a LECO Model 200CS instrument. For this analysis, $300 \mathrm{mg}$ of sample were submitted to a combustion process in oxygen atmosphere at $1,350{ }^{\circ} \mathrm{C}$ and the resulting gases were analyzed with an infrared detector. TGA and DSC were performed on a TA instrument Model Q600 SDT in the $50-1,000{ }^{\circ} \mathrm{C}$ range under an air flow of $50 \mathrm{~mL} \mathrm{~min}^{-1}$. DTG profile was obtained from the derivative of the TGA curve as a function of temperature. Infrared spectra were performed on a Shimadzu spectrometer, IR-Affinity model. For IR analyses, samples were dispersed in potassium bromide and subsequently pressed into tablets that were analyzed in the $4000-400 \mathrm{~cm}^{-1}$ region. The yield of humic acids (Equation 1) was calculated from the mass extracted (HA mass) and initial mass of coal (OC mass).

[HA mass/OC mass] x100 (Equation 1)

The aliphatic/aromatic (Al/Ar), carbonyl/aliphatic $(\mathrm{C}=\mathrm{O} /$ $\mathrm{Al})$ and carbonyl/aromatic components $(\mathrm{C}=\mathrm{O} / \mathrm{Ar})$ ratios observed by infrared spectroscopy were calculated using the ratios of integrated areas of the deconvoluted bands (Butozova, et al., 1998; Rios, et al., 2017), allocated to the aliphatic $\left(3000-2800 \mathrm{~cm}^{-1}\right)$, carbonyl $\left(1700 \mathrm{~cm}^{-1}\right)$ and aromatic $\left(1600 \mathrm{~cm}^{-1}\right)$ components using Lorentzian functions in the QtiPlot software. The influence of the independent experimental variables in the $\mathrm{Al} / \mathrm{Ar}, \mathrm{C}=\mathrm{O} / \mathrm{Al}$, and $\mathrm{C}=\mathrm{O} / \mathrm{Ar}$ ratios in oxidized coal and humic acids, as well as the extraction yields of humic acid, were observed through response surface plots in terms of particle size, concentration of oxidizing agent and oxidation time. In this study, the response surfaces were generated from a data matrix obtained with Renka-Cline algorithms (Renka \& Cline, 1984) using the regular values of two independent variables $(\mathrm{x}, \mathrm{y})$ related to the dependent variable or response (z) of the factorial design, in this case, $\mathrm{Al} / \mathrm{Ar}, \mathrm{C}=\mathrm{O} / \mathrm{Al}$, and $\mathrm{C}=\mathrm{O} / \mathrm{Ar}$ ratios, and the yield of humic acids.

Samples were coded according to the number assigned to the experiments generated by the $3^{3-1}$ factorial design; the coal oxidized in different conditions was designated by OCY where $\mathrm{Y}$ is the condition of the experiment number shown in table 1. The humic acid code used was HAY, where Y corresponds to the conditions used in the oxidation of coal from which the respective humic acids were extracted, except for $\mathrm{AH}-0.063$, AH-0.106 and $\mathrm{AH}-0.150$ samples, which were extracted from unoxidized coal samples, previously ground and sieved to particle sizes of $0.063,0.106$ and $0.150 \mathrm{~mm}$.

\section{Results and discussion}

The elemental analysis of the coal (Table 2) showed a high content of carbon (76.1\%), characteristic of a bituminous coal (Wood, et al., 1983). The coal also had a low amount of sulfur $(0.46 \%)$, which makes it optimal for different applications such as energy generation (Gonsalvesh, et al., 2012; Wijaya \& Zhang, 2012). The coal oxygen content $(16.9 \%)$ was low, which is related to the bituminous rank of the coal.

The TGA and DTG curves shown in figure 1 provide information on the degree of oxidation of coal. An initial mass loss was observed at $100-200{ }^{\circ} \mathrm{C}$ due to the evaporation of water physisorbed in the coal surface. A thermodynamic change was also observed in the DTG curve at $161^{\circ} \mathrm{C}$, where a phenolic decomposition occured (Versan-Kok, 2001; 2012). The second mass loss was observed at around $466{ }^{\circ} \mathrm{C}$, where the carbonization started due to the release of carbon dioxide and water, combustion products of the carbonaceous material. At $550{ }^{\circ} \mathrm{C}$, the main mass loss began, observed in the DTG at $582{ }^{\circ} \mathrm{C}$. This significant mass loss occurs due to various chemical reactions, including formation of liquid and gaseous products, volatilization and combustion of fixed carbon. In this region, methane, carbon monoxide, carbon dioxide, aromatic compounds and other aliphatic compounds with low molecular mass are formed (Versan-Kok, 2012).

The DSC curve showed peaks related to coal combustion and other coal reactions; peaks related to water loss were not observed. The first peak, at approximately $459^{\circ} \mathrm{C}$, represented an exothermic change and emitted $1833 \mathrm{~J} \mathrm{~g}^{-1}$, while in the second reaction zone, at $611^{\circ} \mathrm{C}$, it emitted 11301 $\mathrm{J} \mathrm{g}^{-1}$. The endothermic peak appearing above $1,000{ }^{\circ} \mathrm{C}$ was due to the fusion of ash from coal combustion.

In the FTIR spectrum of coal bituminous (Figure 2), a band at $1.600 \mathrm{~cm}^{-1}$ related to the stretching vibration of $\mathrm{C}=\mathrm{C}$ aromatic bond was observed (Skybová, et al., 2007; Lobartini, et al., 1992). Although coals have aromatic rings in the chemical structure, the band at $3,040 \mathrm{~cm}^{-1}$ was not present, which indicated that aromatic structures in the coal had a high degree of condensation and substitutions. The

Table 2. Characteristics of the unoxided coal

\begin{tabular}{|c|c|c|c|c|c|c|c|c|}
\hline Sample & $\begin{array}{c}\mathrm{C} \\
(\%)\end{array}$ & $\begin{array}{c}\mathbf{H} \\
(\%)\end{array}$ & $\begin{array}{c}\mathbf{O} \\
(\%)\end{array}$ & $\begin{array}{c}\mathrm{N} \\
(\%)\end{array}$ & $\begin{array}{c}\text { S } \\
(\%)\end{array}$ & $\begin{array}{c}\text { Moisture } \\
\text { (\%) }\end{array}$ & $\begin{array}{l}\text { Ash } \\
(\%)\end{array}$ & $\begin{array}{c}\text { Volatile matter } \\
(\%)\end{array}$ \\
\hline Unoxidized coal & 76.1 & 4.4 & 16.9 & 2.1 & 0.46 & 8.8 & 2.3 & 35.9 \\
\hline
\end{tabular}




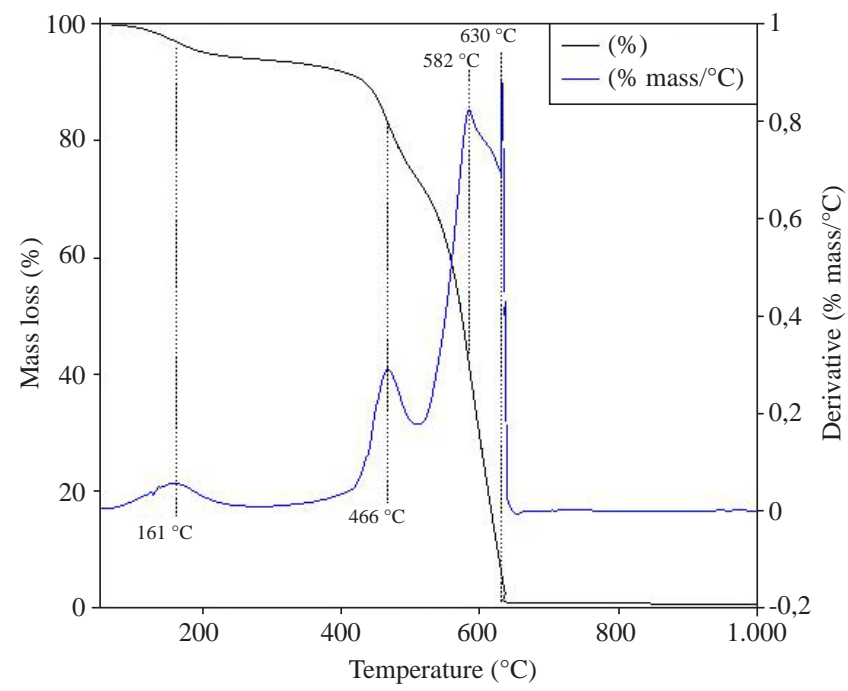

Figure 1. Mass loss and derivative curves of coal from El Cerrejón mine, Colombia

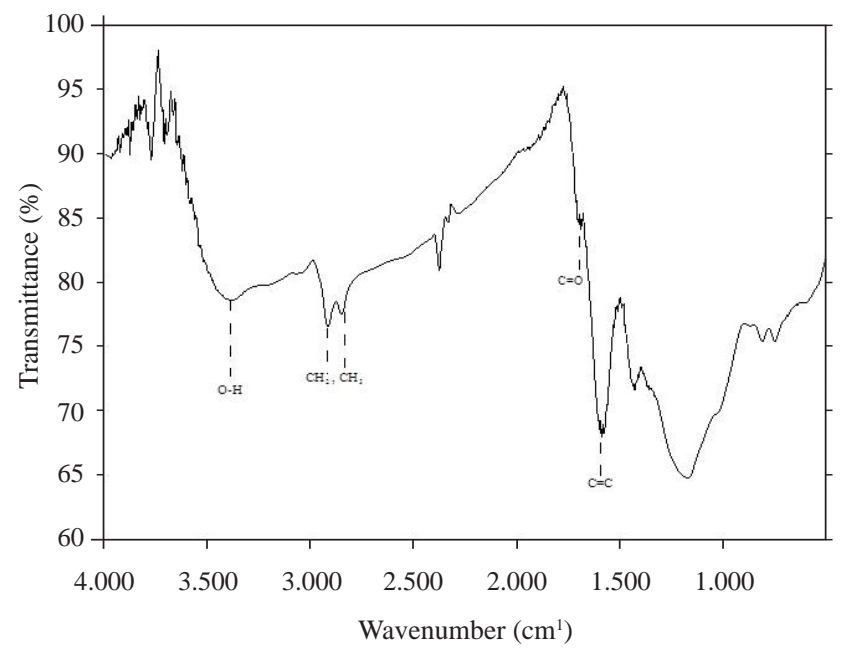

Figure 2. FT infrared spectrum of bituminous coal from El Cerrejon mine, Colombia

$\mathrm{C}-\mathrm{H}$ stretching bands of aliphatic groups $\left(\mathrm{CH}_{2}, \mathrm{CH}_{3}\right)$ were observed at 2,846 and 2,920 $\mathrm{cm}^{-1}$, due to terminal or internal aliphatic chains in the condensed aromatic structures.

In the FTIR spectrum, a carbonyl band with low intensity $\left(1,700 \mathrm{~cm}^{-1}\right)$ was also observed, as well as a broad band centered at $3,400 \mathrm{~cm}^{-1}$, corresponding to $\mathrm{O}-\mathrm{H}$ stretches of carboxyl and/or phenol groups, and another at $3,700 \mathrm{~cm}^{-1}$ for the amide group (Brunetti, et al., 2007).

Oxidized Coal. In the spectra of the oxidized coals (Figure 3), we observed a wide band centered at 3,400 $\mathrm{cm}^{-1}$ due to stretching vibrations of $\mathrm{OH}$ groups in physisorbed water and carboxylic and phenolic groups. In addition, other bands centered at 2,914 and 2,838 $\mathrm{cm}^{-1}$ were caused by stretching of aliphatic groups $\left(\mathrm{CH}_{2}, \mathrm{CH}_{3}\right)$. In the case of bands associated with aliphatic groups, the intensity decreased after oxidation, which indicates that these groups were altered during coal oxidation, favoring the formation of oxygenated groups.

The comparison of the spectra of oxidized and unoxidized coal showed an increase of the $\mathrm{C}=\mathrm{O}$ stretching band $\left(1,700 \mathrm{~cm}^{-1}\right)$ with respect to the band assigned to $\mathrm{C}=\mathrm{C}$ $\left(1,600 \mathrm{~cm}^{-1}\right)$, indicating that the oxidation process favored the formation of carboxyl and/or ketone groups in the carbonaceous matrix.

Table 3 shows the ratios of the peak areas of the aliphatic/ aromatic groups $\left(3,000-2,800 / 1,600 \mathrm{~cm}^{-1}\right)$, carbonyl/aliphatic groups $\left(1,700 / 3,000-2,800 \mathrm{~cm}^{-1}\right)$ and carbonyl/aromatic groups $\left(1,700 / 1,600 \mathrm{~cm}^{-1}\right)$, calculated from the deconvolution of the bands corresponding to these groups. As an illustration example, figure 4 contains the peaks resulting from the deconvolution of the bands of the functional groups under study for the $\mathrm{CO} 1$ oxidized coal.

Most of the Al/Ar values in the oxidized coals were larger than those of the unoxidized coal, suggesting that the oxidation process leads to a higher decomposition/oxidation of the aliphatic coal structure, as it is less affected by the aromatic structures.

The influence of the experimental variables in the $\mathrm{C}=\mathrm{O}$ / $\mathrm{Al}$ ratio is shown in figure 5. In this case, the highest values of the ratio were obtained at intermediate particle size and oxidizing agent concentration $(0.106 \mathrm{~mm}, 0.02$ and $0.05 \mathrm{M}$ $\mathrm{KMnO}_{4}$ ), without a clear dependence on oxidation time. Comparing with the original coal (0.267), an increase of the $\mathrm{C}=\mathrm{O} / \mathrm{Al}$ ratio was observed in all cases, suggesting that oxidation favored the formation of oxygenated groups, which can be formed from the partial oxidation of aliphatic chains or branches in the coal structure.

The effect of oxidation in the aromatic structure of coal determined by the $\mathrm{C}=\mathrm{O} / \mathrm{Ar}$ ratio is shown in figure 6 . In this case, an increase in this ratio occurred in most oxidized products, indicating that part of the aromatic structure was oxidized, with formation of oxygenated groups. In this respect, the oxidation with the highest concentration of the oxidizing agent $(0.05 \mathrm{M})$ was favored, suggesting that the harshest conditions are needed to induce oxidation reactions in the aromatic structure of coal.

With respect to the oxidation time, the greatest oxidation of aromatic components occurred in 60 minutes, showing a decrease of the $\mathrm{C}=\mathrm{O} / \mathrm{Ar}$ ratio when time further increased, which suggests that the process may be leading to a greater oxidation, with decomposition of oxygenated groups and $\mathrm{CO}_{2}$ production, and a lower yield of humic acids.

Humic acids. The FTIR spectra of the humic acids extracted from unoxidized coal at different particle sizes showed the same bands in the region ranging from 4,000 to $2,400 \mathrm{~cm}^{-1}$ attributed to $\mathrm{OH}$ stretching of phenolic and acid groups $\left(3,400 \mathrm{~cm}^{-1}\right)$, and $\mathrm{CH}$ stretching of aliphatic chains or branches $\left(2,914,2,838 \mathrm{~cm}^{-1}\right)$ (Kwiatkowska, et al., 2008; Calemma, et al., 1994). The coal with $0.063-\mathrm{mm}$ particle size yielded a greater humic acid yield (Table 4 ) and humic 


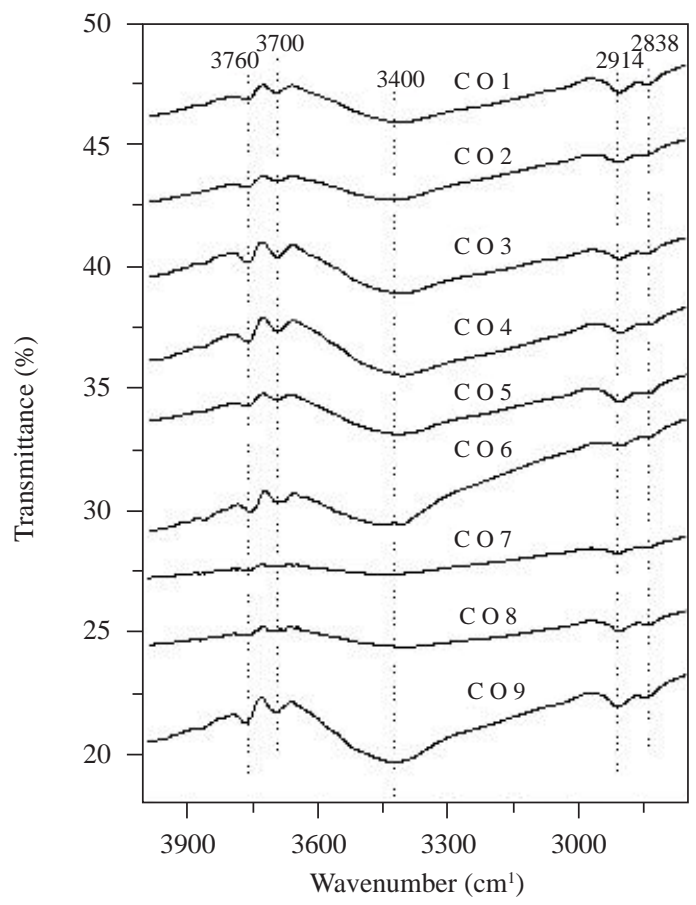

(a)

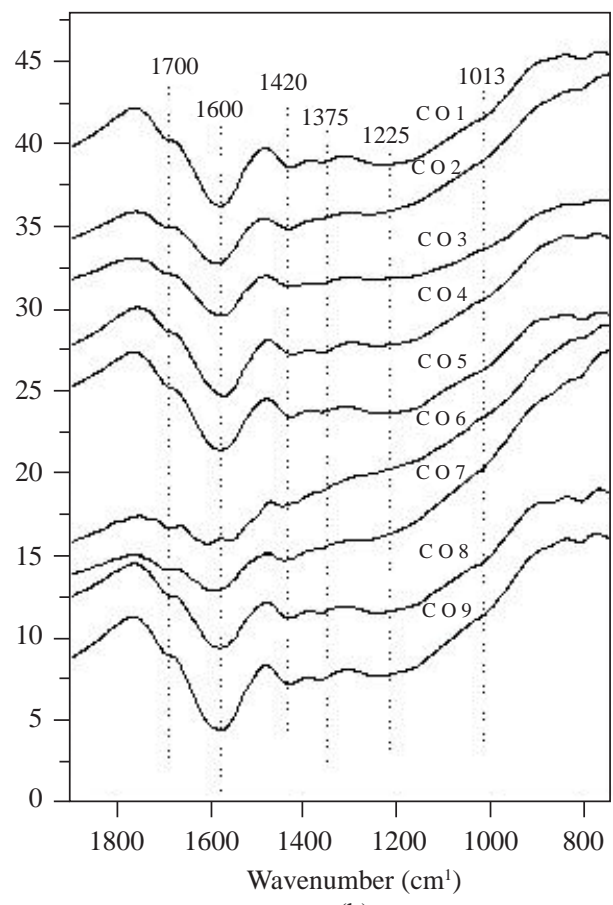

(b)

Figure 3. FTIR spectra of oxidized coal at different conditions: (a) in the 4,000-2,750 $\mathrm{cm}^{-1}$ and (b) $1,900-7,50 \mathrm{~cm}^{-1}$ ranges

Table 3. Ratios of the peak areas of the aliphatic/aromatic ( $\mathrm{Al} /$ $\mathrm{Ar})$, carbonyl/aliphatic $(\mathrm{C}=\mathrm{O} / \mathrm{Al})$ and carbonyl/aromatic $(\mathrm{C}=\mathrm{O} / \mathrm{Ar})$ groups in oxidized coals

\begin{tabular}{llll}
\hline Sample & $\begin{array}{c}\mathbf{A} / \mathbf{A r} \\
\text { ratio }\end{array}$ & $\begin{array}{c}\mathbf{C}=\mathbf{O} / \mathbf{A l} \\
\text { ratio }\end{array}$ & $\begin{array}{c}\mathbf{C}=\mathbf{O} / \mathbf{A r} \\
\text { ratio }\end{array}$ \\
\hline Unoxidized coal & 0.434 & 0.276 & 0.120 \\
CO1 & 0.062 & 0.610 & 0.038 \\
$\mathrm{CO} 2$ & 0.035 & 4.041 & 0.141 \\
$\mathrm{CO} 3$ & 0.205 & 1.702 & 0.235 \\
$\mathrm{CO} 4$ & 0.044 & 2.887 & 0.126 \\
\hline $\mathrm{CO} 5$ & 0.030 & 4.829 & 0.146 \\
$\mathrm{CO} 6$ & 0.026 & 5.011 & 0.130 \\
\hline $\mathrm{CO} 7$ & 0.034 & 3.941 & 0.134 \\
$\mathrm{CO} 8$ & 0.042 & 3.024 & 0.126 \\
\hline $\mathrm{CO} 9$ & 0.032 & 3.586 & 0.116 \\
\hline
\end{tabular}

acids with a larger $\mathrm{OH}$ stretching/CH stretching bands ratio when compared to coals with larger particle sizes. The $\mathrm{C}=\mathrm{O}$ stretching band in the humic acids from unoxidized coal with particle size of $0.106 \mathrm{~mm}$ was more symmetric and pronounced. However, the deconvolution of the aromatic, carbonyl and aliphatic bands suggests that a smaller particle size $(0.063 \mathrm{~mm})$ favored the formation of humic acids with greater $\mathrm{C}=\mathrm{O} / \mathrm{Ar}$ ratio, while the greater $\mathrm{C}=\mathrm{O} / \mathrm{Al}$ ratio in the extracted humic acids occurred in the coal with intermediate particle size, similarly to that observed in the samples of oxidized coal. This may be related to the specific
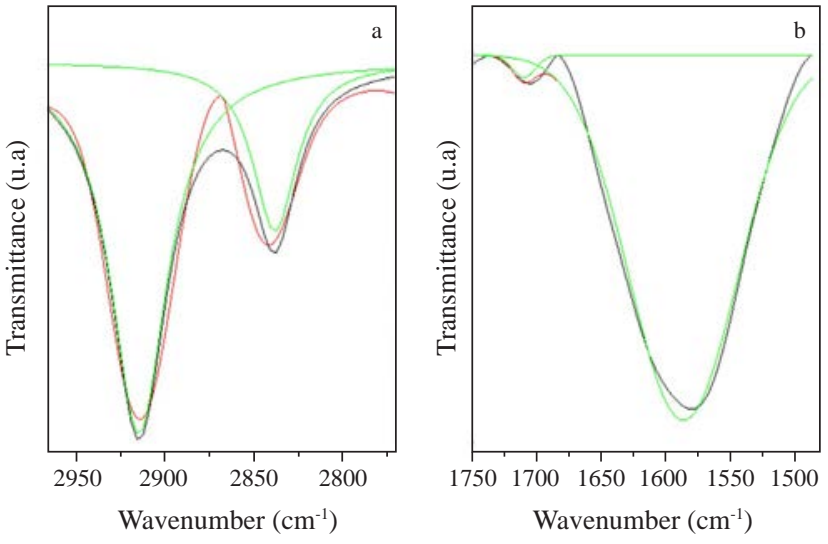

Figure 4. FTIR spectra of CO1 oxidized coal (black line): (a) In the 2,980-2,780 $\mathrm{cm}^{-1}$, and (b) 1,750-1,450 $\mathrm{cm}^{-1}$ ranges. The dotted lines correspond to the bands obtained by deconvolution for the carbonyl and aromatic groups. The solid line is the total result of the deconvolution.

surface area which increases with decreasing particle size contributing to oxidation reactions with atmospheric air of the aliphatic component on the surface. The greater surface area exposed by the solid with smallest particles (AH-0.063) also increased the degree of contact between the alkaline solution used to extract the humic acids from coal, which favored the yield of humic acids (Table 4).

Figure 7 shows that the different types of humic acids obtained from coal oxidation originated very similar FTIR spectra, with bands of the carboxylic and phenolic $\mathrm{OH}$ 

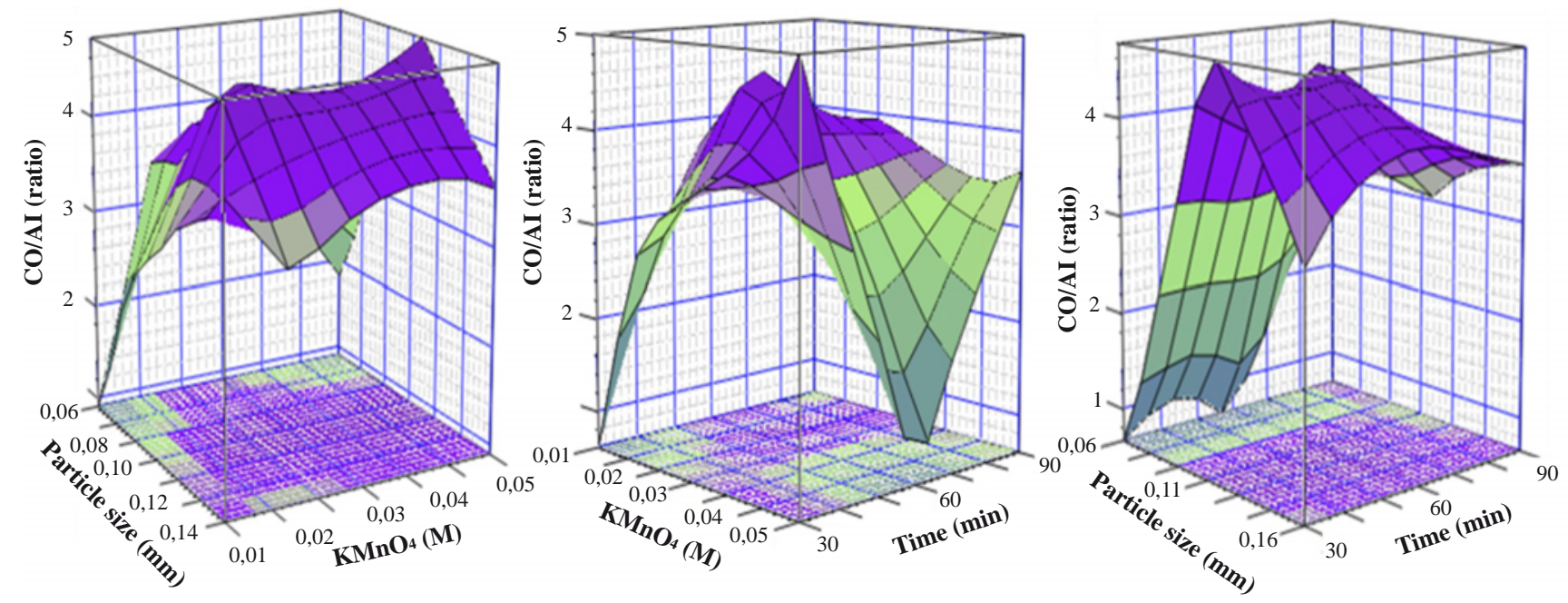

Figure 5. $\mathrm{C}=\mathrm{O} / \mathrm{Al}$ ratio in oxidized coals as a function of the experimental variables used during the oxidation process
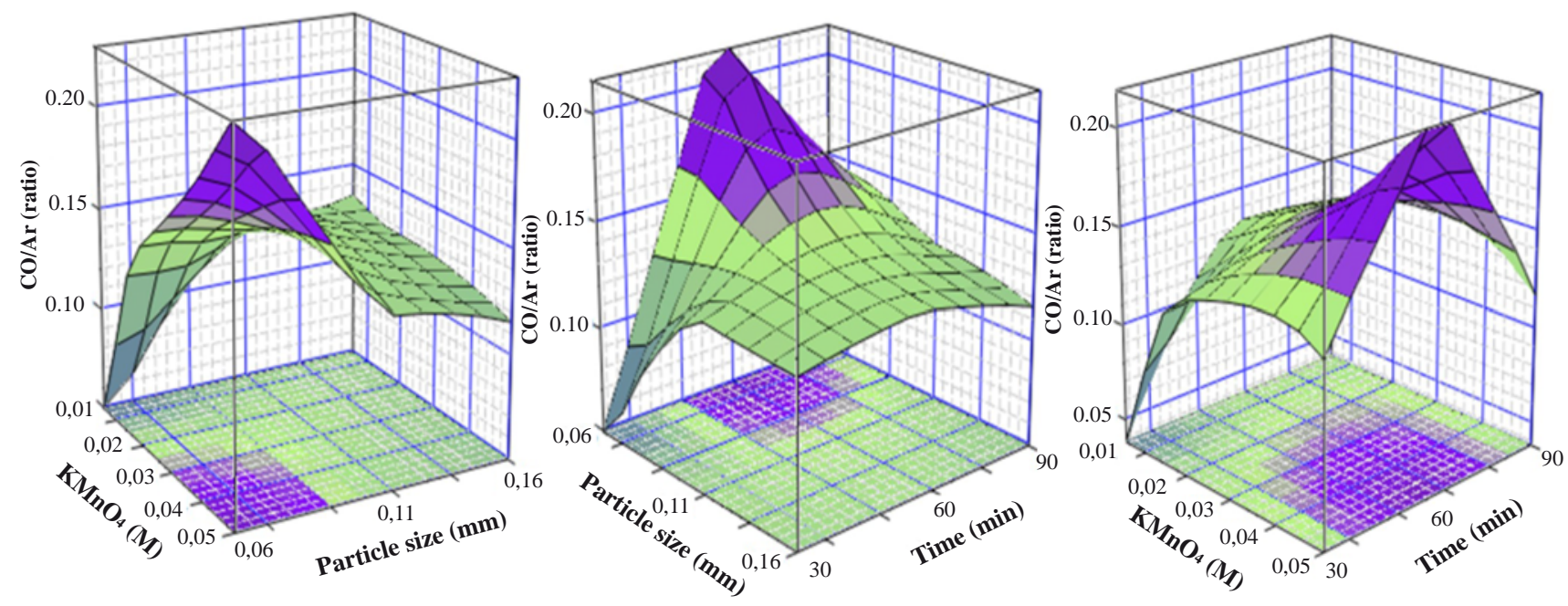

Figure 6. $\mathrm{C}=\mathrm{O} / \mathrm{Ar}$ ratio in oxidized coals as a function of the experimental variables used during the oxidation process

groups at $3,400 \mathrm{~cm}^{-1}$, aliphatic $\mathrm{CH}$ stretching bands at 2,853 and $2,923 \mathrm{~cm}^{-1}$, as well as other bands attributed to carbonyl groups (carboxylic and/or ketone; $1,700 \mathrm{~cm}^{-1}$ ), aromatic ether (Ar-OR; 1,250-1,210 $\mathrm{cm}^{-1}$ ), ether (ROR; 1,300-1,000 $\left.\mathrm{cm}^{-1}\right)$ and aromatic stretching bands $\left(\mathrm{C}=\mathrm{C}, 1,600 \mathrm{~cm}^{-1}\right)$ (Simeoni, et al., 2003; Kurková, et al., 2004; Brunetti, et al., 2007).

Regarding the bands allocated to the aliphatic chains, substantial changes occurred in their shape and intensity, depending on the oxidation conditions used, with a significant reduction in their intensity with oxidation time. According to literature, this is due to oxidation reactions in the aliphatic chains that act as bridges between aromatic structures, giving rise to diverse functional groups (Simeoni, et al., 2003; Brunetti, et al., 2007).

In the case of the $\mathrm{Al} / \mathrm{Ar}$ ratio (Table 4), the lowest values, which imply plenty aromatic components, were observed in humic acids obtained by reaction in the intermediate oxidizing agent concentration $(0.02 \mathrm{M})$. The highest $\mathrm{C}=\mathrm{O} /$ $\mathrm{Al}$ and $\mathrm{C}=\mathrm{O} / \mathrm{Ar}$ ratios occurred in the humic acids extracted from coals oxidized at the highest $\mathrm{KMnO}_{4}$ concentration $(0.05 \mathrm{M})$ indicating a greater amount of oxygenated groups in these products, which makes them more suitable to be used as fertilizers or for removal of heavy metals in water treatment. As shown in table 3, the increase of the $\mathrm{C}=\mathrm{O} / \mathrm{Ar}$ ratio was not as pronounced as that observed in the $\mathrm{C}=\mathrm{O} / \mathrm{Al}$ ratio, suggesting that the samples of oxidized coal with high aromatic content have less humic material.

The response surface in figure 8 shows that the highest yields of humic acids were obtained by oxidation of the samples with smaller particle size $(0.063 \mathrm{~mm})$, in the intermediate time $(60 \mathrm{~min})$ and the intermediate concentration of the oxidizing agent $(0.02 \mathrm{M})$. The most important factors to increase the content of humic acids by coal oxidation were the contact area between particles (particle size) and the oxidizing solution concentration, achieving extraction yields 
Table 4. Ratios of the peak areas of the aliphatic/aromatic (Al/ $\mathrm{Ar})$, carbonyl/aliphatic $(\mathrm{C}=\mathrm{O} / \mathrm{Al})$ and carbonyl/aromatic $(\mathrm{C}=\mathrm{O} /$ Ar) groups in humic acids extracted and extraction yield from oxidized coals

\begin{tabular}{lcccc}
\hline Sample & $\begin{array}{c}\mathbf{A} / \mathbf{A r} \\
\text { ratio }\end{array}$ & $\begin{array}{c}\mathbf{C}=\mathbf{O} / \mathbf{A l} \\
\text { ratio }\end{array}$ & $\begin{array}{c}\mathbf{C}=\mathbf{O} / \mathbf{A r} \\
\text { ratio }\end{array}$ & $\begin{array}{c}\text { Humic } \\
\text { acids a }\end{array}$ \\
\hline AH-0.063 & 0.186 & 8.053 & 1.500 & $5.8 \pm 0.1$ \\
\hline AH-0.106 & 0.074 & 16.770 & 1.233 & $5.2 \pm 0.1$ \\
AH-0.150 & 0.056 & 18.306 & 1.095 & $4.6 \pm 0.1$ \\
\hline AH1 & 0.291 & 3.348 & 0.973 & $11.2 \pm 0.2$ \\
AH2 & 0.060 & 15.545 & 0.937 & $24.4 \pm 0.3$ \\
\hline AH3 & 0.094 & 17.536 & 1.642 & $24.0 \pm 0.3$ \\
AH4 & 0.076 & 12.460 & 0.947 & $5.9 \pm 0.1$ \\
\hline AH5 & 0.085 & 15.651 & 1.335 & $8.3 \pm 0.1$ \\
\hline AH6 & 0.081 & 20.267 & 1.647 & $7.4 \pm 0.2$ \\
\hline AH7 & 0.223 & 6.111 & 1.362 & $7.4 \pm 0.1$ \\
AH8 & 0.093 & 9.650 & 0.898 & $8.0 \pm 0.2$ \\
\hline AH9 & 0.111 & 16.600 & 1.835 & $7.0 \pm 0.1$ \\
\hline
\end{tabular}

a: Extraction (\%)

above $24 \%$ for the $0.063-\mathrm{mm}$ particle size coal. These results are close to those obtained by Zhiyuan, et al. (2012) using $\mathrm{HNO}_{3}$ as an oxidizing agent in the presence of catalysts, and higher than those obtained by Skybová, et al. (2017), who used mechanochemical activation of brown coals. Previous studies carried out in our laboratory (Anillo-Correa, et al., 2013) on lignite-type coals allowed to obtain yields higher

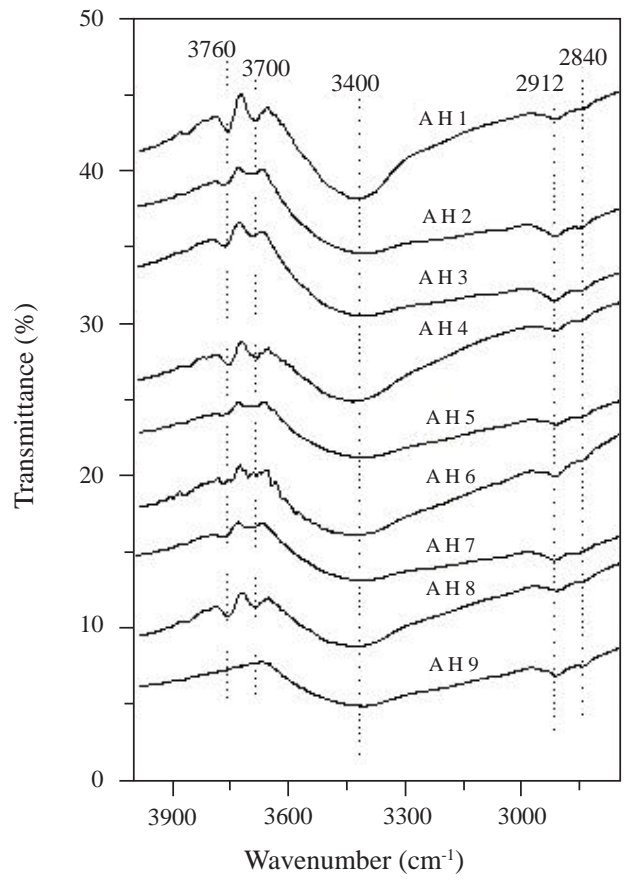

(a) than $80 \%$, which was attributed to previous oxidation with air at different temperatures, followed by oxidation with $\mathrm{HNO}_{3}$ or $\mathrm{H}_{2} \mathrm{O}_{2}$. In this case, the lowest extraction yield was attributed to the higher degree of maturation of the coal (76.1\% of carbon), which has lower content of oxygenated groups than brown coal and lignites.

The extraction yields of humic acids indicate that when the reaction was performed with the largest time (90 minutes) and particle sizes $(0.106$ and $0.150 \mathrm{~mm})$ the content of humic acids decreased. This may be due to a longer time of interaction between the $\mathrm{KMnO}_{4}$ solution and the coal, which led to decomposition of the oxygenated groups previously formed. This effect was also evident for all the concentrations of $\mathrm{KMnO}_{4}$.

Oxidation at intermediate concentrations of $\mathrm{KMnO}_{4}$ $(0.02 \mathrm{M})$ and smaller and intermediate particle sizes favored the production of carbonyl groups in the structure of humic acids, which increased their extraction yield.

\section{Conclusions}

The oxidation process led to increased decomposition and/ or oxidation of the aliphatic coal structure; in this case, the bands associated with aliphatic groups decreased after coal oxidation, which indicates that the aliphatic chains or branches were altered, favoring the formation of oxygenated groups. The aromatic structures were less affected and the oxidation with the highest concentration of the oxidizing agent was favored, suggesting that the harshest conditions are needed to induce oxidation reactions in the aromatic structure of coal.

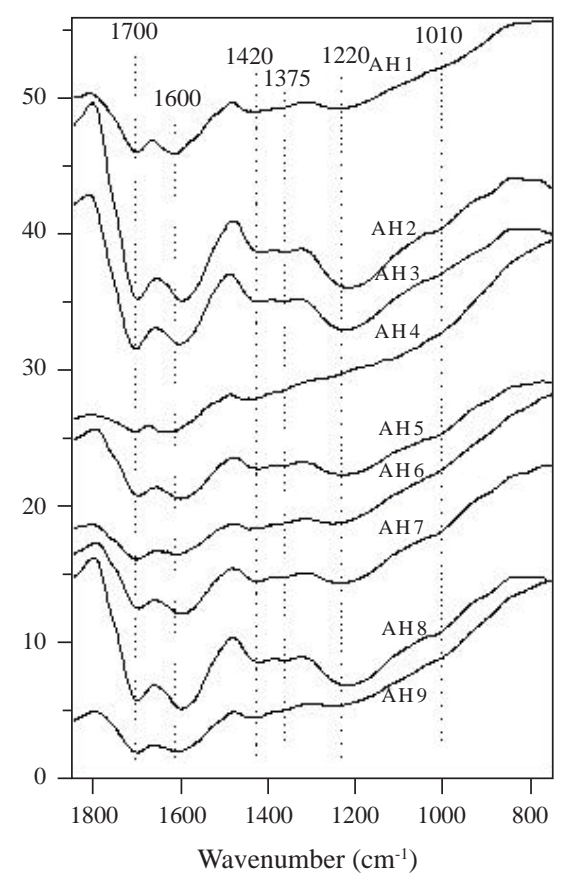

(b)

Figure 7. FTIR spectra of humic acids extracted form oxidized coals in the 4,000-2,750 $\mathrm{cm}^{-1}$ (a) and 1,900-750 $\mathrm{cm}^{-1}$ (b) ranges 

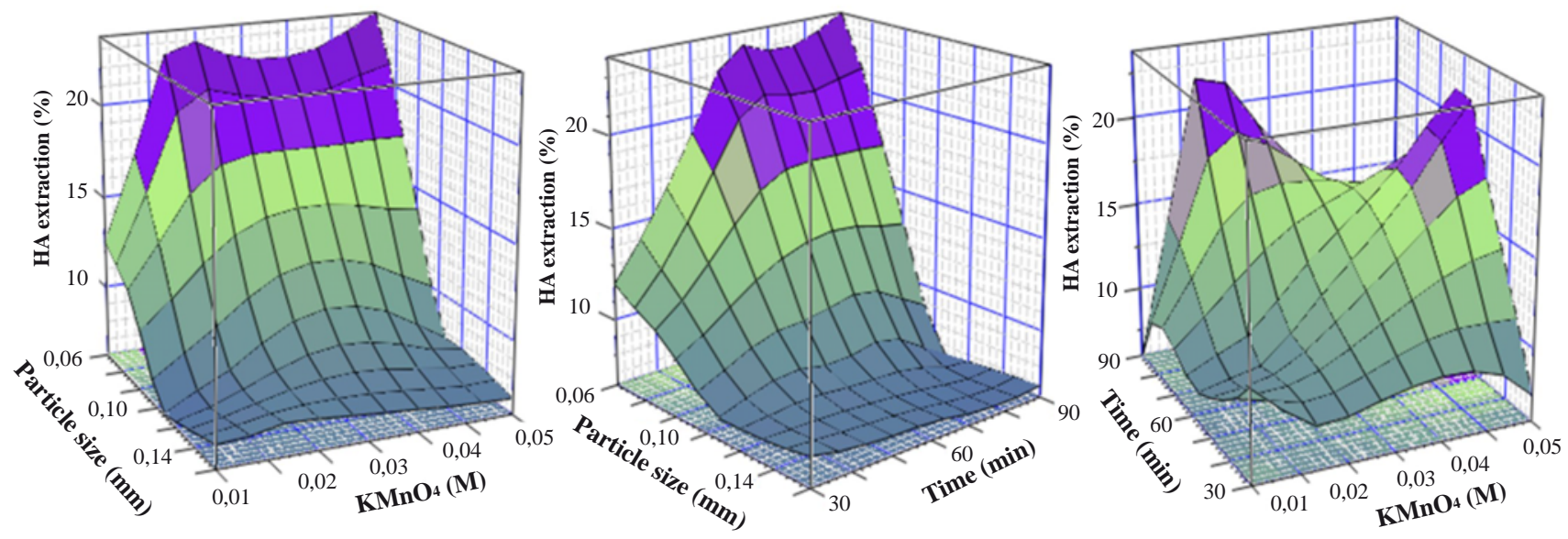

Figure 8. Extraction yield of humic acids form oxidized coals as a function of the experimental variables used during the oxidation process

The humic acids obtained from coal oxidized at differents conditions originated FTIR spectra with substantial changes in the shape and intensity of bands allocated to the aliphatic structure due to oxidation reactions in the aliphatic chains that act as bridges between aromatic structures, giving rise to diverse functional groups.

The highest yields of humic acids were obtained by oxidation of the samples with small particle size, and in the intermediate time and concentration of the oxidizing agent (60 min and $0.02 \mathrm{M}$, respectively). The most important factors to increase the content of humic acids by coal oxidation were the contact area between particles (particle size) and the oxidizing solution concentration, achieving extraction yields above $24 \%$ for $0.063-\mathrm{mm}$ particle-size coal. These results are close to those obtained using brown coals and lignite, which suggests that bituminous coals with high carbon content can be used to obtain humic materials using moderate oxidation conditions and easy manipulation, with diluted concentrations of $\mathrm{KMnO}_{4}(0.02 \mathrm{M})$ and short time periods $(60 \mathrm{~min})$.

\section{Contribución de los autores}

APP, realizó los experimentos relacionados con la oxidación del carbón, extracción, cuantificación y caracterización de los ácidos húmicos y el análisis de los resultados obtenidos. EEF, asesoró el proyecto y realizó el análisis de los grupos funcionales por espectroscopia infrarroja. FCC, analizó los resultados relacionados con la caracterización del carbón y de los ácidos húmicos obtenidos, participó en la redacción y revisión del artículo. JRR, caracterizó los materiales por las técnicas FTIR, TGA y DSC, elaboró el diseño factorial y la interpretación de las superficies de respuesta. RFL, analizó e interpretó estadísticamente los resultados, participó en la redacción y corrección del artículo. EMF, autor del proyecto de investigación, participó en la interpretación de los resultados y en la elaboración de las superficies de respuesta y en la redacción y revisión del artículo.

\section{Acknowledgments}

Universidad de Cartagena and SENA-Centro para la Industria Petroquímica.

\section{Conflic of interest}

The authors declares no conflict of interests.

\section{References}

Anillo-Correa, R., Colpas-Castillo, F., Meza-Fuentes, E. (2013). Aumento del contenido de ácidos húmicos en un carbón de bajo rango a través de la oxidación con aire y con peróxido de hidrogeno o ácido nítrico. Quim. Nova 2013. 36: 387-392.

Barros, B., Scarminio, I., Bruns, E (1996). Planejamento e Otimização de Experimentos (Second edition). Edit. Unicamp, Campinas, Brasil. p. 149-296.

Brunetti, G., Plaza, C., Clapp, C., Senesi, N. (2007). Compositional and functional features of humic acids from organic amendments and amended soils in Minnesota, USA. Soil. Biol. Biochem. 39: 1355-1365.

Butuzova, L., Krzton, A., Bazarova, O. (1998). Structure and properties of humic acids obtained from thermo-oxidised brown coal. Fuel. 77: 581-584.

Calemma, V., Iwansski, P., Rausa, R., Girardi, E. (1994). Changes in coal structure accompanying the formation of regenerated humic acids during air oxidation. Fuel. 73: 700-707.

Espinosa-Fuentes, E., Colpas-Castillo, F., Meza-Fuentes, E. (2017). Estudio teórico de las interacciones de dos modelos de ácidos húmicos con los cationes $\mathrm{Al}^{3+}, \mathrm{Ca}^{2+}, \mathrm{Mg}^{2+}, \mathrm{Zn}^{2+}$, $\mathrm{K}^{+}$y $\mathrm{NH}_{4}^{+}$a un nivel de cálculo dft y un modelo de solvatación PCM. Quim. Nova. 40: 299-304.

Gomes de Melo, B., Lopes, F., Andrade, M. (2016). Humic acids: Structural properties and multiple functionalities for novel technological developments. Mater. Sci. Eng. C. 62: 967-974.

Gonsalvesh, L., Marinov, S., Stefanova, M., Carleer, R., Yperman, J. (2012). Organic sulphur alterations in biodesulphurized low rank coals. Fuel. 97: 489-503.

Jones, M. \& Bryan N. (1998). Colloidal properties of humic substances. Adv. Colloid. Interface Sci. 78: 1-48. 
Kawasaki, S., Maie, N., Kitamura, S., Watanabe, A. (2008). Effect of organic amendment on amount and chemical characteristics of humic acids in upland field soils. Eur. J. Soil Sci. 59: 1027-1037.

Klučáková, M. \& Kalina, M. (2015). Diffusivity of $\mathrm{Cu}(\mathrm{II})$ ions in humic gels-influence of reactive functional groups of humic acids. Colloids. Surf., A: Physicochem. Eng. Aspects. 483: 162-170.

Klučáková, M. \& Věžníková, K. (2017). Micro-organization of humic acids in aqueous solutions. J. Mol. Struc. 1144: 30-40.

Kumada, K. (1987). Chemistry of Soil Organic Matter. Developments. Soil. Sci. 17: 17-33.

Kurková, M., Klika, Z., Kliková, C., Havel, J (2004). Humic acids from oxidized coals I. Elemental composition, titration curves, heavy metals in HA samples, nuclear magnetic resonance spectra of HAs and infrared spectroscopy. Chemosphere. 54: 1237-1245.

Kwiatkowska, J., Provenzano, M., Senesi, N. (2008). Long term effects of a brown coal-based amendment on the properties of soil humic acids. Geoderma. 148: 200-205.

Liang, L., Lv, J., Luo, L., Zhang, J., Zhang, S. (2011). Influences of surface-coated fulvic and humic acids on the adsorption of metal cations to $\mathrm{SiO}_{2}$ nanoparticles. Colloids. Surf., A: Physicochem. Eng. Aspects. 389: 27-32.

Lobartini. J., Gingle, A., Pape, C., Himmelsbach, D. (1992). The geochemical nature and agricultural importance of commercial humic matter. Sci. Total. Environ. 113: 1-15.

MacCarthy, P. (2001) The principles of humic substances. Soil Sci. 166: 738-751.

Martínez-Fernández, D., Arco-Lázaro, E., Bernal, M., Clemente, R. (2014). Comparison of compost and humic fertiliser effects on growth and trace elements accumulation of native plant species in a mine soil phytorestoration experiment. Ecol. Eng. 73: 588-597.

Morgenthaler, S., Schumacher, M. (1999). Robust analysis of a response surface design. Chemometr. Intell. Lab. 47: 127-141.

Nebbioso, A., Piccolo, A. (2012). Advances in humeomics: Enhanced structural identification of humic molecules after size fractionation of a soil humic acid. Anal. Chim. Acta. 720: 77-90.

Raposo, J., Villanueva, U., Olivares, M., Madariaga, J. (2016). Determination of humic substances in sediments by focused ultrasound extraction and ultraviolet visible spectroscopy. Microchem. J. 128: 26-33.

Rashid, M., Price, N., Gracia, M., O'Shea K. (2016). Effective removal of phosphate from aqueous solution using humic acid coated magnetite nanoparticles. Water Res. 123: 153-160.

Renka, R. \& Cline, K. (1984). A triangle-based $C^{1}$ interpolation method. J. Math. 14: 223-238.

Ríos-León, I., Solano-Polo, C., Rodríguez-Ruiz, J., EspinosaFuentes, E., Meza Fuentes, E. (2017). Estudio a través de espectroscopia infrarroja y termogravimetría del efecto de la temperatura en hidrotalcitas de níquel y aluminio. Dyna. 84: 9-16.
Saldaña-Robles, A. Saldaña-Robles, N. Saldaña-Robles, A.L., Damián-Ascencio, C. Rangel-Hernández, V.H. GuerraSánchez, R. (2017). Arsenic removal from aqueous solutions and the impact of humic and fulvic acids. J. Clean. Prod. 159: 425-431.

Shaker, M. \& Albishri H. (2014). Dynamics and thermodynamics of toxic metals adsorption onto soil-extracted humic acid. Chemosphere. 111: 587-595.

Simeoni, M., Batts, B., McRae, C. (2003). Effect of groundwater fulvic acid on the adsorption of arsenate by ferrihydrite and gibbsite. Appl. Geochem. 18: 1507-1515.

Skybová, M., Turčániová, L', Čuvanová, S., Zubrik, A., Hredzák, S., Hudymáčová, L. (2007). Mechanochemical activation of humic acids in the brown coal. J. Alloy. Compd. 434: 842-845.

Stevenson, F. (1994). Humus Chemistry: Genesis, Composition, Reactions. First edition. New York: John Wiley \& Sons, United States. p. 1-19.

Tang, K., Escola M., Ooi G., Kaarsholm K., Bester K., Andersen H. (2017). Influence of humic acid addition on the degradation of pharmaceuticals by biofilms in effluent wastewater. Int J Hyg Envir Heal. 220: 604-610.

Taraba, B. (1990). Reversible and irreversible interaction of oxygen with coal using pulse flow calorimetry. Fuel. 69: 1191-1199.

Tejeda-Agredano, M., Mayer, P., Ortega-Calvo, J. (2014). The effect of humic acids on biodegradation of polycyclic aromatic hydrocarbons depends on the exposure regime. Environ. Pollut. 184: 435-442.

Van Krevelen D.W. (1993). Coal: Typology-Physics-ChemistryConstitution. Edit. Elsevier, Amsterdam. p. 249-292.

Versan-Kok, M. (2001). An Investigation into the combustion curves of lignites. J. Thermal. Anal. Calorimetry. 64: 13191323.

Versan-Kok, M. (2012). Simultaneous thermogravimetry-calorimetry study on the combustion of coal samples: Effect of heating rate. Energy. Convers. Manage. 53: 40-44.

Wijaya, N. \& Zhang, L. (2012). Generation of ultra-clean fuel from Victorian brown coal-Synchrotron XANES study on the evolution of sulphur in Victorian brown coal upon hydrothermal upgrading treatment and thermal pyrolysis. Fuel. 99: 217-225.

Wood, G., Kehn, T., Carter, M., Culbertson, W. (1983). Coal Resource Classification System of the U.S. Geological Survey, Geological Survey: Denver, United States.

Yang, K., Miao, G., Wu. W., Lin, D., Pan, B., Wu, F., Xing, B. (2015). Sorption of $\mathrm{Cu}^{2+}$ on humic acids sequentially extracted from a sediment. Chemosphere. 138: 657-663.

Zhang, S., Yuan, L., Li, W., Lin, Z., Li, Y., Hu, S., Zhao B. (2017). Characterization of $\mathrm{pH}$-fractionated humic acids derived from Chinese weathered coal. Chemosphere. 166: 334-342.

Zhiyuan, Y., Liang, G., Pan, R. (2012). Preparation of nitric humic acid by catalytic oxidation from Guizhou coal with catalysts. Int. J. Mining. Sci. Tech. 22: 75-78. 